Orientalia Christiana Cracoviensia 8 (2016), s. 53-71

DOI: http://dx.doi.org/10.15633/ochc.2197

Marcin Rzepka

Uniwersytet Papieski Jana Pawła II w Krakowie

\title{
The Bible, the Boundaries and the Christian Missionary Initiatives in the Caucasus During the Nineteenth Century: General Remarks
}

\begin{abstract}
The Bible, the Boundaries and the Christian Missionary Initiatives in the Caucasus During the Nineteenth Century: General Remarks. The article presents the main missionary organizations both Protestant and Orthodox working in the Caucasus in the nineteenth century. By presenting them in a rather general and brief form, the article is intended to emphasize the importance of the Bible translations in the missionary projects. The Bible itself constitutes a text which influences the missionary approach, as well as the cultural and social practices of the people to whom the Bible and its translation is addressed. The main assumption of the text is, however, that the changing attitudes to the Bible among the Christians living in the Caucasus were related to the appearance of the Protestants and their understanding of the Holy Book.
\end{abstract}

Keywords Christianity, Protestantism, missions, Bible, Caucasus, Tiflis 
The history of the Caucasus in the nineteenth century reveals changes in social and cultural affiliations of the people inhabiting the area which became politically integrated with the Russian Empire. ${ }^{1}$ The cultural approach to study the changes and transformations, processes of creation and re-creation of social and political borders and boundaries, ways of crafting and expressing identities or belongings offers the concept of translation as a useful theoretical frame to integrate particular and divided histories of ethnic, religious and socio-cultural groups across the Caucasus. It emphasizes the social, cultural and political actions rather then actors. Thus, translation understood not merely as a linguistic or textual operation grounds cultures, establishes affiliation, constructs identities. The cultural approach arises awareness of the function of translation indicating the asymmetries of the cultural systems well seen in a multicultural reality of the Caucasus. ${ }^{2}$

At the beginning of the nineteenth century the Caucasus as a part of the Russian Empire caused an incredible inflow of the Christian population, Assyrians and Armenians, from the neighboring countries - Ottoman Turkey and Qajar Persia, involving them into contacts with both Muslim communities and the Russian authorities. They also attracted attention of both Protestant and Orthodox Churches attempting to make them part of their own Church structures, to convert them, or, at least, to support them. On the geopolitical scene the Russian Empire signing the Turkmenchay Treaty with Persia in 1828 confirmed its dominant position almost all over the Caucasus. But later, in the middle of the century after the defeat of the Imam Shamil forces, Russia revealed its broader project to integrate the region not only formally but also culturally. Thus, Christianization became a form of civilization. ${ }^{3}$ In practice, the implementation and realization of the Orthodox missionary idea in the nineteenth century depended on the political changes and social developments of the Empire, and was shaped or re-shaped by the Russian rulers, governors and Church elites. At the beginning of the century, religious

1 The article is an expanded and revised version of the paper presented during the conference Religions of the Caucasus organized by the European Azerbaijan Society which was held in London on 3-4 March 2014. The paper was published in Baku, however without author's revision, under the title: Crossing Boundaries, Crafting Religious Identities. Eastern Christians and Western Missionaries in the Caucasus During the First half of the $19^{\text {th }}$ Century, in: Religions in the Caucasus. A Collection of Essays and Articles, Baku 2016, p. 185-202.

2 Cf. F. Mostashari, On the Religious Frontier: Tsarist Russia and Islam in the Caucasus, LondonNew York 2006, p. 37-46.

3 The different Russian ideas and actions to know and dominate over the Caucasus are presented in detail in: A. Jersild, Orientalism and Empire. North Caucasus Mountain Peoples and the Georgian Frontier 1845-1917, Montreal-London-Ithaca 2002, p. 3-11, 38-58. 
ideas and arrangements, including the establishment of missionary institutions, were determined by tsars Alexander I and Nicolay I, whose policy had a great impact also upon the Protestant initiatives in the whole Russia in general and in the Caucasus in particular.

Over a century a significant number of various Protestant groups arriving in the Caucasus tried to conduct their activity, whether missionary or social, hoping to find followers, adherents or just peace to live as colonizers who were granted privileges by the Russian Emperor. Whatever they hoped to find, they, in fact, came into contacts with religions, faiths and confessions influencing the concepts, attitudes and behavior of the people inhabiting the Caucasus at that time. Some of them turned their attention to the missionaries for different reasons. Among them were Russians from the Christian heterodox groups, Georgians, Ossetians, Azerbaijanis, Nogais, and others, including the new-comers like Armenians, ${ }^{4}$ many of whom had become Protestants in the Ottoman Turkey, and Assyrians. The South Caucasus was transformed by the intensive missionary enterprises into the zone of rivalry and cooperation, the channel of transferring modern ideas crossing the borders, the place of social, economic and political mobilization.

By presenting the chosen Protestant and Orthodox missionary initiatives undertaken in the nineteenth century, the article is aimed at depicting the role of the Bible, its translations, distribution and dissemination among the Caucasian Mountaineers in forming new ideas, crafting new identities and inventing new professions. Thus, missionaries can be categorized as entrepreneurs and the Bible as the source of social and cultural changes. The problems of the interactions between Protestants and Orthodox Christians, their mutual influences and interferences are definitely not of a smaller importance in the context of history of the missions in the Caucasus in "the age of steam and print."

\section{The Orthodox and Protestant Missionary Initiatives: Politics and History}

The political and religious changes at the turn of the eighteenth and nineteenth centuries caused by the weakening of the Ottoman Empire, the expansion of the European power, and the growing missionary zeal among

4 More about the Armenian Protestantism see: L. Arpee, A Century of Armenian Protestantism, "Church History" 5 (1936) no. 2, p. 150-167; L. Arpee, The Armenian Awakening, ChicagoLondon 1909. 
different Churches shaped Christianity in its global and local forms. After the Treaty of Küçük Kaynarca in 1774 Russia started expressing its role as the protector and the guarantor of the rights of the Eastern Christians who had been subordinated to the Muslim rulers. Such claims were also applied to the Christians in the Caucasus - Georgians against Persians. In 1811 the Georgian Exarch was established, which, in practice, meant the absorption of the Georgian church and complete integration with the Russian Orthodox structures. ${ }^{5}$ A slightly different approach was undertaken by Russians in their contacts with the Armenian Apostolic Church and the Assyrian Church of the East, small in number, represented mainly in Tiflis and Erivan Governorate. The contacts and interactions with the great powers influenced the political aspirations of tiny Christian groups scattered among the Muslims. A good example being the activity of the Assyrian Patriarch and the bishops of the Assyrian Church seeking protection from the British or the Russian Empire, which resulted in establishing the last foreign mission of the Russian Orthodox Church addressed to the Assyrians and situated in Persia on the Urmia plain. ${ }^{6}$ Systematically, however, the idea of missionary work among the Caucasian Muslim groups attracted the Orthodox Church elites. First among the Muslims in the North Caucasus ${ }^{7}$ and later - in the middle of the century - in its southern part. Alexander Baryatinsky, who hoped to Christianise the Caucasus not "by sword but mercy and love," was among the founders of the Society for the Restoration of Orthodox Christianity in the Caucasus (Общество восстановления православного христианства на Кавказе), an influential and well-organized institution, based in Tiflis. ${ }^{8}$ The Society cooperated with some Protestant missions in the field of the Bible translations and the Bible distribution.

The nineteenth century protestant missionary movement - the result of the religious changes occurring in Europe and the USA and the heir of the Pietism and spiritual revivals from the former centuries - emphasised the necessity of the Bible translation for all people into the languages into which

5 Cf. История Грузинской иерархии, с присовокуплением обращения в христианство Осетии и других горских народов, по 1-е января 1825 года, Москва 1826, p. 20-22.

6 Сf. С. М. Садо, Российская православная миссия в Урмии (1898-1918), “Христианское чтение” 1996 № 13, p. 73-112.

7 Cf. M. Tarran, The Orthodox Mission in the North Caucasus - End of 18th - Beginning of the 19th Century, "Central Asian Survey" 10 (1991) no. 1-2, p. 103-117.

8 Cf. M. Gnolidze-Swanson, Activity of the Russian Orthodox Church Among the Muslim Natives of Caucasus in Imperial Russia, "Caucasus and Central Asia Newsletter" 2003 issue 4, p. 9-19. 
the Bible had not been translated yet. On the other hand, Protestants took the idea of the religious conversion as central in their missionary plans. Focusing on the Bible itself and the conversion became a common experience for different protestant groups categorized as Evangelical. ${ }^{9}$ Such concepts also influenced the Russian Evangelicals. ${ }^{10}$

The early Protestant missionary activity in the Caucasus was involved in the missions among the Muslim people not only in this region but also beyond the borders, especially in Persia. However, before long, following the events after the above-mentioned 1828 agreement, when Armenians and Assyrians were migrating en masse to the Caucasus, the local and Eastern Christians became the Protestant missionary concern. ${ }^{11}$ Yet there were some limitations which made the Protestant missionary hard to conduct. The hegemonic position of Russia on this territory caused a real problem for Protestants. Nikolay I rescinded the permission issued previously by Alexander I for Scottish missionaries, which terminated the mission. Every form of the missionary activity among the members of the Orthodox church was strictly banned. It is worth mentioning that the Caucasus was also a safe haven for heterodox Christian groups such as Dukhobors and Molokans, ${ }^{12}$ some of whom turned into Protestantism. ${ }^{13}$

The Scottish Missionary Society (Edinburg Missionary Society) operating in Astrakhan and Karass in the northern Caucasus between 1802-1835 was granted privileges to develop missionary activity by Tsar Alexander I. $\mathrm{He}$ also advocated the idea of establishing the Russian Bible Society, ${ }^{14}$ an organization based upon the ideas of the British and Foreign Bible Society, in 1813 with Prince Golitzin as its head. ${ }^{15}$ Its role in popularizing the Bible

9 Cf. M. A. Noll, Evangelical Identity, Power, and Culture in the 'Great' Nineteenth Century, in: Christianity Reborn. The Global Expansion of Evangelicalism in the Twentieth Century, ed. D. M. Lewis, Cambridge 2004, p. 31-51.

10 Cf. G. Pełczyński, Ewangelikalizm w Rosji (XIX-XX wiek), Poznań 2013, p. 72-89.

11 Till the end of 1829 105,000 Armenians from Ottoman Turkey and Persia were settled in the Caucasus; see: F. Mostashari, On the Religious Frontier..., op. cit., p. 41.

12 Cf. S. I. Zhuk, Russia's Lost Reformation: Peasants, Millennialism, and Radical Sects in Southern Russia and Ukraine, 1830-1917, Washington 2004, p. 37, 106-118.

13 Cf. R. Lunkin, A. Prokof, Molokans and Dukhobors: Living Sources of Russian Protestantism, "Religion, State and Society" 28 (2010) no. 1, p. 87-88.

14 Cf. J. C. Zacek, The Russian Bible Society and the Russian Orthodox Church, "Church History" 35 (1966) no. 4, p. 411-437.

15 Сf. О Библейских Обществах и учреждении таковаго же в Санктпетербурге, Санкт-Петербург 1813, p. 24-27. 
among the Caucasian nations is hard to be overestimated and, of course, its role in creating a religious culture should be underlined.

In 1820s and 1830s also the missionaries from the Basel Mission concentrated on the southern part of the Caucasus. Because of its non-denominational character, the organization was also involved in common projects with the Bible Societies. Following the missionary policy, a number of Anglicans, Presbyterians, Lutherans, Mennonites, Baptists and later Pentecostals settled down among the Caucasians. What should be emphasised is the remarkable commitment in the Bible translation work.

We may present the main Protestant missionary organizations operating in the region in the nineteenth century pointing out the established centres and languages they were focused on along with the representatives, workers, and missionaries.

Table 1. Main Protestant Societies working in the Caucasus

\begin{tabular}{|c|c|c|c|}
\hline $\begin{array}{c}\text { Missionary } \\
\text { Societies }\end{array}$ & $\begin{array}{c}\text { Some } \\
\text { representatives }\end{array}$ & $\begin{array}{c}\text { Activity area - } \\
\text { main cities }\end{array}$ & $\begin{array}{c}\text { Languages } \\
\text { and the Bible } \\
\text { translation projects }\end{array}$ \\
\hline $\begin{array}{c}\text { Scotish Missionary } \\
\text { Society } \\
1802-1835\end{array}$ & $\begin{array}{c}\text { Henry Brunton } \\
\text { Alexander Paterson } \\
\text { John Mitchell } \\
\text { Robert Ross } \\
\text { Galloway } \\
\text { William Glen }\end{array}$ & $\begin{array}{c}\text { Astrakhan } \\
\text { Karass }\end{array}$ & $\begin{array}{c}\text { Azerbaijani } \\
\text { Kalmuk }\end{array}$ \\
\hline $\begin{array}{c}\text { Basel Mission } \\
1821-1835\end{array}$ & $\begin{array}{c}\text { Felician Zaremba } \\
\text { August Dietrich } \\
\text { Karl Gottlieb Pfander }\end{array}$ & $\begin{array}{l}\text { Shusha } \\
\text { Baku }\end{array}$ & $\begin{array}{l}\text { Armenian } \\
\text { Azerbaijani } \\
\text { Kurdish }\end{array}$ \\
\hline $\begin{array}{c}\text { British and Foreign } \\
\text { Bible Society } \\
\text { with auxiliary Bible } \\
\text { Societies } \\
11 \text { January } 1813 \text { - } \\
\text { Russian Bible Society } \\
30 \text { August } 1818 \text { - } \\
\text { auxiliary society } \\
\text { in the Caucasus }\end{array}$ & $\begin{array}{c}\text { Ebenezer Henderson } \\
\text { (1820s) } \\
\text { John Melville (1850s) } \\
\text { James Watt (1870s) } \\
\text { Michael Morrison } \\
\text { (1870s) }\end{array}$ & $\begin{array}{c}\text { Tiflis } \\
\text { Vladikavkaz } \\
\text { Pyatigorsk }\end{array}$ & $\begin{array}{c}\text { Georgian } \\
\text { Armenian } \\
\text { Persian } \\
\text { Ossetian }\end{array}$ \\
\hline
\end{tabular}

Sources: E. Henderson, Biblical Researches and Travel in Russia; Including a Tour in the Crimea and the Passage of the Caucasus, London 1826, p. 430-432, 512; M. Jones, The Sad and Curious Story of Karass, 1802-35, "Oxford Slavonic Papers" 8 (1975), New Series, p. 53-81; J. Urry, John Melville and the Mennonites: A British Evangelist in South Russia, 1837 - ca. 1875, "Mennonite Quarterly Review” 54 (1980), p. 305-322; M. Rzepka, Konfesyjność przekladu. Kulturowa historia kurdyjskich tłumaczeń Biblii, Kraków 2013, p. 121-140; W. Canton, A History of the British and Foreign Bible Society, vol. 2, London 1904, p. 278. 
We may assume that the concept of the Bible translation with the presumption that "the Bible is the best missionary on its own" is a characteristic feature of the Protestant missionary movement. Thus, the necessity of taking the Bible, its translation, interpretation and reception into consideration and searching for the contexts in which such translations and interpretations appeared is a research proposal to be adopted in discussions on the Christianity in the Caucasus in the nineteenth century. Practically, all the missionaries mentioned in Table 1 offer interesting case-studies on general translation strategies, relations between religious zeal and politics, or particular cultural practices concerning the Bible. Ebenezer Henderson, for instance, observed the practices of removing the Bible or any other religious book from a house of an ill person to prevent it from "the evil influence." According to him, such practices were common among the Armenians living in Mozdok, who in this region were "grossly superstitious." ${ }^{\text {" It }}$ is evidence of a kind of superstitious treatment of the Bible as an extraordinary book not designed to be read. In fact, it helps to explain the roots of the negative reaction toward the Bible colporteurs offering the Bible in native languages and the reluctance to modern translations among the Armenians from the Armenian Apostolic Church in the first half of the nineteenth century. ${ }^{17}$ Even nowadays the Bible interpretation made by the representatives of the nations and communities living in the Caucasus shows a tendency to use the biblical text in order to prove their rights to live in the political boundaries and is used by some of them to manifest their primacy on the Caucasian soil. Such interpretations seem to be more nationalistic rather than religious.

There is no doubt that following the Protestants the new ways of reading the biblical texts were introduced among the people living in the Caucasus, a kind of private and personal reading became more common.

\section{The Protestant Activity in the Caucasus: Enculturation of the Bible}

In our attempt to answer the question on the contacts between the Protestants and the Eastern churches existing in the Caucasus we should underline the

16 E. Henderson, Biblical Researches..., op. cit., p. 467.

17 William Canton described much more positive attitudes towards the Bible and its distributors among the Caucasian Muslims than among Armenians from the national Church, see: W. Canton, A History of the British and Foreign Bible Society, vol. 3, London 1904, p. 361. 
dominant position of the Russian Orthodox Church. Thus, the essential relations between Protestants and the Orthodox Church on the one hand and the Armenians and heterodox groups such as Molokans on the other - should be taken into consideration. What is more, some representatives of such heterodox minority Christians became later "native" Protestants. A good example is a Molokan, merchant Nikita Voronin who played a significant role in planting Protestant - Baptist communities in and around Tiflis. ${ }^{18}$

In the case of the Armenian Church the representatives of the Basel Mission tried to contact the Catholicos in Etchmiadzin in order to persuade him into the modern translation of the Armenian Bible with rather modest results. Felician Zaremba, ${ }^{19}$ a Polish missionary, working with this organization together with August Dietrich at that time, was responsible for these contacts, and also translated part of the Bible with Mirza Farukh into the Azerbaijani language. Zaremba kept good relations with the agents of the British and Foreign Bible Society not only in Russia but also in Ottoman Turkey and Persia. In fact, the Caucasus for a while took the central position in the evangelisation and missionary projects addressed both to Eastern Christians and to Muslim communities. ${ }^{20}$

Julius Richter, a historian of the Protestant Eastern missions, characterized him as follows:

The committee saw in him a personality specially fitted to put their Caucasus Mission on a firm footing. By his complete command of the Russian language and thorough knowledge of Russian state affairs he was marked as the man to conduct the many complicated negotiations with the Russian authorities. ${ }^{21}$

18 Cf. С. Н. Савинский, История евангельских христиан-баптистов Украины, России, Белоруссии, Санкт-Петербург 1999, p. 130-131. See also: M. Songulashvili, Evangelical Christian Baptists of Georgia: The History and Transformation of a Free Church Tradition, Waco (Texas) 2015.

19 Ein russischer Edelmann als Missionar: Aus d. Leben von Dr. Felician von Zaremba, Basel 1890; A. Katterfeld, Felician von Zaremba ein Christuszeuge im Kaukasus, Stuttgart 1939.

20 Henry Leeves - the Bible Society agent from Constantinople admired his activity to promote the Bible translation into Modern Armenian, which proves Zaremba's talents and contacts with the religious and political authorities in the Caucasus, see: Cambridge University Library, The British and Foreign Bible Society archives (here after: BSA), BSA, DI/2, Leeves to Steinkopff, May 10, 1824.

21 J. Richter, A History of Protestant Mission in the Near East, Edinburgh-London 1910, p. 99. 
Recalling the society choice and the appointment of Zaremba, Richter enhanced his qualifications and responsibility to carry on the negotiations with the Russians, who ruled over the Caucasus. We may presume that the "hard talks" with the Russian authorities would bring agreement and permission to lead the missionary activity among the individuals and communities under the Russian law. It does not mean the opportunity to work among the Orthodox Christians but among others - Christian heterodox, Armenians or Muslims.

\section{The Bible Translation and Religious Conversions}

The translation of the Bible was one of the main objects of missionary activity. It was assumed that the translation itself might be influential in people's decision to become Christians, or - as it was stressed during the Reformation - to deepen and revitalize the Christian faith. Hence, a big number of Protestant initiatives to translate the Bible not only for the Caucasian people who were not in possession of any Christian text in their own language but also to translate, or re-translate the Bible for the members of old and traditional Christian Churches. What is interesting is the fact that in the early period of Protestant missionary activity in the Caucasus the Bible translation into Persian ${ }^{22}$ was regarded as the most suitable for the Muslims in the South Caucasus ${ }^{23}$ - especially in Baku and Elizavetpol Governorates. The Persian Bible translation by Henry Martyn was printed for the first time in 1816 in Petersburg and circulated on the Russian-Persian borderland. ${ }^{24}$ In fact the geographical distribution of languages and the range of their usage determined the missionary work. It is well-seen in initiatives undertaken to spread the Christian message among the Muslims. Canton suggests that the Arabic Bible was accepted

22 Cf. W. Glen, Journal of a Tour from Astrachan to Karass, North of the Mountains of Caucasus, Edinburgh 1823, p. 68.

23 Cf. C. Bennett, The Legacy of Karl Gottlieb Pfander, "International Bulletin of Missionary Research" 20 (1996) no. 2, p. 76-81. The author gave the following description of Pfander: "He believed that if Muslim read the New Testament in Persian, their preferred language, they would automatically acknowledge 'its true and superiority' and would abandon Islam."

24 More on Bible translations into Persian, see: M. Rzepka, Translacja i konwersja. Językowe i kulturowe aspekty przekładu Ewangelii na język perski, Kraków 2012; N. Green, The Trans-Colonial Opportunities of Bible Translation: Iranian Language-Workers between the Russian and British Empires, in: Trans-Colonial Modernities in South Asia, eds. M. Dodson, B. Hatcher, London 2012, p. 116-136. 
in Dagestan while the Persian translations were distributed in a region from Ararat to Shusha and the Caspian coast. ${ }^{25}$

It is worth emphasizing that it was not only Christians but also Muslims subjects of the Persian king - who arrived in the territories of the South and North Caucasus. Probably, the most famous one being Alexander (Mirza Mohammad Ali) Kazembek, who, after his conversion to Christianity, became a professor of the Oriental languages at the University of Kazan. Undoubtedly, the change of religion, apostasy from Islam by the son of the minister of the Fath-Ali shah court had to elicit some social reaction. The first one came from a rather unexpected side. An Orthodox bishop opposed to the plans of Alexander Kazembek's baptism in the Protestant church, which, in fact, indicated the complexity of the protestant and Orthodox relations in the Caucasus. However, having obtained the permission from the Department of the Religious Affairs in Petersburg, Kazembek was baptised by William Glen, a Scottish missionary, and the baptismal ceremony was conducted in three languages: English, Turkish and Persian. ${ }^{26}$ No conversion was a purely religious act of will. Robert Ross from the Scottish Mission in his short account of Kazembek's personal abilities and his wish to become a missionary placed the events into a political context and explained why he had never become a missionary. Alexander Kazembek as a Christian and the subject of Russia was invoked to the Imperial service. Ross explains:

It was hoped that he would soon be able to give himself entirely up to the duties of a missionary, than which there was nothing he himself more earnestly desired. [...]

But in the autumn of 1824, all such hopes were suddenly destroyed by the arrival of an order from General Yermoloff, the governor-general of the southern provinces of Russia, commanding the Persian convert to enter into the service of the emperor, but allowing him to select the department in which he would prefer being employed. ${ }^{27}$

Possibilities of free Protestant missionary activity were limited by the political circumstances. However, the intensity of the missionary efforts large-

25 Cf. W. Canton, A History..., vol. 2, op. cit., p. 270.

26 Cf. R. Waterfield, Christians in Persia. Assyrians, Armenians, Roman Catholics and Protestants, London 1973, p. 99.

27 R. Ross, The Persian Convert, in: The Christian Keepsake and Missionary Annual, ed. W. Ellis, London-Paris-New York 1836, p. 166. 
ly influenced the local Christians in their approach toward the Bible, and on the other hand - religious conversion. Thus, the dissemination of the idea of the Bible translation into vernacular languages, modern and understandable along with the pressure to publish and distribute low-priced and easy-to-reach Bibles, changed the official position of the Church authorities, such as the Holy Synod, toward the individual usage of the Bible, and also changed the traditional view on the language of the canonical texts used in the Church service.

Similarly, attitudes to the conversion treated by Protestants as an individual and personal act of faith released this idea from its predominantly political understanding, more or less shared in the Church and State circles. Despite, of course, the Russian state policy after all, we should consider the nineteenth-century imperialism which strengthened, supported and encouraged the Orthodox missions. A good example being the change of the Church affiliation by some of the Assyrians living in the Caucasus, who sent a petition to unite with the Orthodox Church. In the meantime, a written request sent by the Muslims who emigrated to the Caucasus in which they expressed their wishes to be Orthodox Christians, should be seen as a political act rather than a religious one.

In the Central Historical Archive in Tbilisi we can find materials concerning the Orthodox missionary movement in the region, including information about the Muslim converts, which, although rare, seems to be very important in analyzing both the political stance of the Church and missionary prospects. We can find at least two files related to the Muslims from Persia - Samad-oglu ${ }^{28}$ and Useynov ${ }^{29}$ - who were baptized in the Orthodox rite. The documents, unfortunately, are silent about the reasons for their conversion, focusing rather on the expenditure on the baptismal ceremony. The religious conversion means changing loyalties and priorities and involves a convert in the process of re-creating or re-constructing the self. The conversion may also become a tool used by the powerful state or church to unify citizens or believers.

28 The National Archives of Georgia - Sakartvelos Erovnuli Arkivi [here after: SEA], The Central Historical Archive - Saistorio Tsentraluri Arkivi [here after: STA], SEA, STA, f. 493, 18521882, d. 394 (О приведении в Православную веру магометанина, персидского подданного Маносру Самад-оглы).

29 SEA, STA, f. 493, 1852-1882, d. 417 (О приведении в Православную веру персидского подданного магометанина Асана Усеинова). 
The conversion, as it can be seen in the Caucasian context, might also result in the process of deethnization of an individual or a group. It seems obvious that the existence of the Bible translation into one's language is an indicator of their identity and it might have stopped such a process. While analysing the Protestant activity in the Caucasus we may assume that their impact on the Eastern Christians was manifested on two levels. Firstly, in the attitude toward the Bible, changing the view on its translation and its personal usage. Secondly, in the conversion, and what is connected with its personal responsibility for one's own spiritual development.

\section{Possible Protestant Influence on the Eastern Churches}

Perhaps, the most visible impact of the above-mentioned core Protestant concepts on the other Churches may be observed in the activity and growth of the Orthodox missionary organizations at that time. Although the Orthodox missionary initiatives have a long history, the quality of missionary enterprises changed notably in the nineteenth century. Certainly, the Russian idea of the Christianization of the Caucasus became part of the mission of civilization of the Russian Empire. As such, there is no huge difference between the Russian missions and, for instance, the Anglican missions in Africa or India - they were supported by the Colonial State. The qualitative change may be seen in the adoption of a variety of strategies concerning the Bible, translation, language and education. We may presume that the new methods and strategies were formulated among the Orthodox missionaries under the Protestant influence.

The evidence to prove it is as follows:

1) The intensive contacts with Protestant missionaries, especially in the context of the Bible translation initiatives, like translation into Russian, Georgian, Armenian, Ossetic, and other languages.

The intensity of the contacts depended upon the number of Protestant missionaries, the geographical distribution of the missionary stations and the support which the missionaries received from the European organizations sending them into the Caucasus. Such contacts were of a different character: political and administrative on the one hand and religious on the other. The Protestants were obliged to obtain special permissions to conduct their activity, which in fact was subject to the total control of the state and permanent observation by the Church authorities. 
2) The acquaintance with the Protestant missionary "know-how" based on the deep understanding of the function and development of the missionary stations operating in the Caucasus.

As an example we may recall the correspondence among the Russian Orthodox Church authorities on the Protestant missionary library left after the Scottish mission station had been closed, which may prove quite useful in such study. ${ }^{30}$ The library collection included different translations of the Bible into languages spread among the Caucasian people, religious books and articles, which might provide a deep insight into the Protestant missionary strategies, hopes and difficulties and, which is quite probable, might also inspire to establish the collections at Orthodox schools and missionary stations. We may recall at least a project by an Orthodox priest in Qax (Zaqatala region) to establish a missionary and anti-Muslim library. ${ }^{31}$

A good example of the cooperation, competition and confrontation between the Protestants and the Russian Orthodox Church is the activity of the Russian Bible Society and the clash of ideas concerning the Bible translation. ${ }^{32}$ In the second half of the nineteenth century the Protestants and the Russian Orthodox Church representatives cooperated in Tiflis publishing and distributing the Bible translations into Georgian as well as several other languages. Having analysed the correspondence of the Bible Society agents John Melville and Michael Morrison, it became clear that the civilian and religious authorities in the Caucasus were familiar with the main Protestant ideas connected to the Bible - its translation and printing. In his letter to the Board of the Society for Restoration of the Orthodox Christianity in the Caucasus, Morrison tried to persuade the Society to print the new edition of the Georgian Bible under the principles accepted by the British and Foreign Bible Society, which meant that the edition of the Bible would not comprise any commentary, deuterocanonical books would not be included, the price would correspond to the value or, if possible, it would be sold for a symbolic price, under the value of the printed book. ${ }^{33}$ We may expect that

30 Cf. SEA, STA, f. 493, 1852-1882, d. 63 (О приобретении для Общества книг, рукописей и разных обзаведении бывшей Шотландской миссии).

31 Cf. SEA, STA, f. 493, 1852-1882, d. 750 (Об открытии миссионерской противо-мусульманской библиотеки при Кахской церкви Закатальского округа).

32 See detailed history of Russian Bible Society and its relations with the Holy Synod: S. K. Batalden, Russian Bible Wars. Modern Scriptural Translation and Cultural Authority, Cambridge 2013.

33 Cf. SEA, STA, f. 493, 1852-1882, d. 346 (Morris to the Society for Restoration of the Orthodox Christianity in the Caucasus, 5 December 1879). 
some of these concepts might have been accepted by the Orthodox Church, especially as they did not touch openly the theological matters but rather the practical ones.

During the first half of the nineteenth century several Protestant missionary stations were established. In the North - in Karass with Scottish, and next German missionaries, in the South - in Shusha with missionaries from the Basel Mission. It is well-seen, however, that the missionary activity developed faster in the second half on that century. Tiflis, with its growing population of the Evangelical Russian Christians (mostly Baptists), seems to have been the most important place for the Protestants at that time. An agency of the British and Foreign Bible Society was opened in the city dealing with publishing and distribution of the Bibles in a variety of native languages. William Canton in his history of the British and Foreign Bible Society gathered some information about the interests toward the Bibles sold by the "Tiflis Bible depôt" indicating that in only six months of 1875 more than 4,000 copies were sold and the buyers included: a Georgian bishop, a Muslim mullah, Persian Jews, and others. ${ }^{34}$ Tiflis as a multi-cultural city and the centre of the Russian governorate of the Caucasus must have attracted the attention of missionaries and in the meantime brought them into intensive contact with Eastern Christians, especially Georgians and Russians. ${ }^{35}$

Tiflis also played a crucial role in the Russian Orthodox plans to Christianize the Caucasus. It was from there that the Society for Restoration of the Orthodox Christianity in the Caucasus, headed at the beginning by Prince Baryatinsky, conducted its missions. The program of the organization is very similar to the documents of this kind circulating among Protestants it resembles the programs of the British and Foreign Bible Society and the Church Missionary Society, focusing, of course, its attention on the Caucasus. Comparing the documents we may assume that two elements are of special consideration: the Bible translation and education - establishing the schools as a broader missionary project.

Concerning the translation, we can find the following statement in the program of the Society of the Orthodox Christianity in the Caucasus:

34 Cf. W. Canton, A History..., vol. 3, op. cit., p. 356.

35 Canton gave a picturesque description of the city from the Protestant perspective: "In Tiflis itself the civilization and fashions of the West mingled with the colour and squalor of Oriental cities. Each trade had its own street or quarter, and each man carried on his industry in public" (W. Canton, A History..., vol. 3, op. cit., p. 360). 
The Council of the Society is giving a special attention to the translation of the Holy Scriptures into the native languages and dialects, taking all the print expenses on its own. Such translation should be prepared into Svan and Abkhaz languages and first of all into Ossetic language, and after this into other languages used in the mountainous regions of the Caucasus. The translated Bibles will be distributed among the mountainous people through the educated in schools, learned men and missionaries, and with other methods, accepted by the Council. ${ }^{36}$

The program presents the priorities in conducting missionary efforts making translation their main object. But the Bible distribution is a task of native missionaries rather than of educated strangers. Thus, translation means a process to prepare a native community of readers and believers through the network of educational centres and elementary work among the young generation of the targeted nation. It resembles the very modern missiological concept, which in the second half of the nineteenth century occupied the Protestant missionary writings. ${ }^{37}$

It is worth emphasising the place of the Ossetic people in the Orthodox missionary imagination in the nineteenth century. The Ossetians who had not been fully Christianised were also under the influence of Islam spreading in the middle of the century among Caucasians in the mystical form of muridism. That caused serious missionary efforts to protect them from such Islamic impact and turn them into good Orthodox Christians. The success of the Orthodox mission may be seen as an ideological victory over Islam and pagan religions in the borderland regions. Such ideas are manifested in the program of the Society and in the letters of Baryatinsky. The restoration and strengthening of the Orthodoxy among the Caucasian mountaineers was the main goal through which they expected to establish "Christianity victorious not suffocated faith." ${ }^{38}$

The importance of the mission to the Ossetic people is well seen in the quantity of the reports issued by the special Orthodox Ossetic Council. The progress is also seen in the number of the Ossetic registered as Orthodox

36 SEA, STA, f. 493, 1852-1882, d. 1 (Устав Общества Восстановления Православного Христианства на Кавказе).

37 Cf. P. Williams, 'Not Transplanting': Henry Venn's Strategic Vision, in: The Church Missionary Society and World Christianity 1799-1999, eds. K. Ward, B. Stanley, London 2000, p. 155.

38 SEA, STA, f. 493, 1852-1882, d. 1, Устав Общества Восстановления Православного Христианства на Кавказе. 
believers with stable condition. For instance, in the period 1848-1859, a rise from 31,669 in 1848 to 53,995 in 1859 was observed. The report contains a lot of detailed data.

Table 2. Development of the Orthodox Christianity among Ossetians

\begin{tabular}{|c|c|c|c|c|}
\hline Year & $\begin{array}{c}\text { Total number } \\
\text { of Ossetian } \\
\text { Christians }\end{array}$ & $\begin{array}{c}\text { Number } \\
\text { of new believers }\end{array}$ & $\begin{array}{c}\text { Number } \\
\text { of the people } \\
\text { attending to the } \\
\text { Saint Irina day }\end{array}$ & $\begin{array}{c}\text { Number of the } \\
\text { people receiving } \\
\text { the Sacrament } \\
\text { of Confession }\end{array}$ \\
\hline 1848 & 31,669 & 936 & 2,069 & 1,355 \\
\hline 1850 & 42,260 & 1,088 & 1,484 & 758 \\
\hline 1856 & 49,257 & 1,878 & 7,028 & 2,028 \\
\hline 1859 & 53,995 & 3,286 & 9,544 & 2,305 \\
\hline
\end{tabular}

Source: SEA, STA, f. 493, 1852-1882, d. 24.

As we can see in Table 2 the growing number of the Church members does not indicate their participation in the Orthodox Church holidays (as the Saint Irina day mentioned in the report) or religious practices like the Holy Confession. The problem became depicted by the author of the report, who emphasised the necessity of work among children of the newly Christianized people to prepare them for the future missionary activity among their tribesmen. We can observe that during the implementation of the nineteenth century missionary programs both the Protestants and the Orthodox gradually converged themselves.

Summing up, we can emphasise the importance of the Caucasus in the Protestant missionary concepts in the nineteenth century. The multi-ethnic, multi-linguistic and multi-religious region attracted the attention of Protestants who came from different churches. However, they soon turned to the Christian communities in the Caucasus trying to Evangelize or re-Evangelize them. Similarly, the Russian Orthodox church conducted its Caucasus missions focusing on Christians, like Ossetians.

Above all, we should observe that following the Protestants arrival in the Caucasus the Bible and its translations became a missionary tool. The extensive projects covered translation into several languages from different linguistic groups. What is more, they changed the attitudes toward the Bible among the Eastern Christians creating new practices of reading and interpreting the Bible. The Bible and its translation as well as their multiple functions: edu- 
cational, religious, cultural and political should be subject to further studies on the nineteenth-century Christianity in the Caucasus.

Analysing the changes and transformations which became part of the life of the Caucasian Christians in the nineteenth century through the lens of the Bible translations and its editions - the Bible is a constitutive text for Christianity after all - may bring a deeper qualitative outlook on the conditions and requirements of the Christianity in the Caucasus. It may refresh the analysis focusing on the research on the religious practices connected to the Bible reading - communal and individual, as well as on the role of the text, the Bible, in formulating self-identity. The Bible is becoming a text which crosses the religious boundaries in a symbolic manner, becoming a cultural or even political text. In this context the postcolonial biblical hermeneutics of R. S. Sugirtharajah ${ }^{39}$ would prove influential in such research, of course with some modification to the Caucasian uniqueness. The attitudes toward the Bible were changing under particular social and political circumstances and the Bible itself was used in different situations as a source of authority, inspiration or polemics. The practices of reading also changed in time. Some of them were noticed by the missionaries who came into contact with the members of the Eastern Churches.

\section{Bibliography}

\section{Archival sources:}

Cambridge University Library, The British and Foreign Bible Society archives (BSA), BSA, DI/2 (Foreign corresp. inwards; Leeves, H.D., Letters 1823-1827).

The National Archives of Georgia - Sakartvelos Erovnuli Arkivi (SEA), The Central

Historical Archive - Saistorio Tsentraluri Arkivi (STA), f. 493, 1852-1882.

\section{Books, articles:}

Arpee L., A Century of Armenian Protestantism, "Church History" 5 (1936) no. 2, p. 150-167. Arpee L., The Armenian Awakening, Chicago-London 1909.

Batalden S. K., Russian Bible Wars. Modern Scriptural Translation and Cultural Authority, Cambridge 2013.

39 R. S. Sugirtharajah, The Bible and the Third World. Precolonial, Colonial and Postcolonial Encounters, Cambridge 2004; R. S. Sugirtharajah, Exploring Postcolonial Biblical Criticism: History, Method, Practice, Oxford 2012. 
Bennett C., The Legacy of Karl Gottlieb Pfander, "International Bulletin of Missionary Research" 20 (1996) no. 2, p. 76-81.

Canton W., A History of the British and Foreign Bible Society, vol. 2-3, London 1904.

Ein russischer Edelmann als Missionar: Aus d. Leben von Dr. Felician von Zaremba, Basel 1890.

Glen W., Journal of a Tour from Astrachan to Karass, North of the Mountains of Caucasus, Edinburgh 1823.

Gnolidze-Swanson M., Activity of the Russian Orthodox Church Among the Muslim Natives of Caucasus in Imperial Russia, "Caucasus and Central Asia Newsletter" 2003 issue 4, p. 9-19.

Green N., The Trans-Colonial Opportunities of Bible Translation: Iranian Language-Workers between the Russian and British Empires, in: Trans-Colonial Modernities in South Asia, eds. M. Dodson, B. Hatcher, London 2012, p. 116-136.

Henderson E., Biblical Researches and Travel in Russia; Including a Tour in the Crimea and the Passage of the Caucasus, London 1826.

Jersild A., Orientalism and Empire. North Caucasus Mountain Peoples and the Georgian Frontier 1845-1917, Montreal-London-Ithaca 2002, p. 3-11, 38-58.

Jones M., The Sad and Curious Story of Karass, 1802-35, “Oxford Slavonic Papers” 8 (1975), New Series, p. 53-81.

Katterfeld A., Felician von Zaremba ein Christuszeuge im Kaukasus, Stuttgart 1939.

Lunkin R., Prokof A., Molokans and Dukhobors: Living Sources of Russian Protestantism, "Religion, State and Society" 28 (2010) no. 1, p. 87-88.

Mostashari F., On the Religious Frontier: Tsarist Russia and Islam in the Caucasus, LondonNew York 2006, p. 37-46.

Noll M. A., Evangelical Identity, Power, and Culture in the 'Great' Nineteenth Century, in: Christianity Reborn. The Global Expansion of Evangelicalism in the Twentieth Century, ed. D. M. Lewis, Cambridge 2004, p. 31-51.

Pełczyński G., Ewangelikalizm w Rosji (XIX-XX wiek), Poznań 2013.

Richter J., A History of Protestant Mission in the Near East, Edinburgh-London 1910.

Ross R., The Persian Convert, in: The Christian Keepsake and Missionary Annual, ed. W. Ellis, London-Paris-New York 1836, p. 155-168.

Rzepka M., Konfesyjność przekładu. Kulturowa historia kurdyjskich tłumaczeń Biblii, Kraków 2013.

Rzepka M., Crossing Boundaries, Crafting Religious Identities. Eastern Christians and Western Missionaries in the Caucasus During the First half of the $19^{\text {th }}$ century, in: Religions in the Caucasus. A Collection of Essays and Articles, Baku 2016, p. 185-202.

Rzepka M., Translacja i konwersja. Językowe i kulturowe aspekty przekładu Ewangelii na język perski, Kraków 2012.

Songulashvili M., Evangelical Christian Baptists of Georgia: The History and Transformation of a Free Church Tradition, Waco (Texas) 2015. 
Sugirtharajah R. S., The Bible and the Third World. Precolonial, Colonial and Postcolonial Encounters, Cambridge 2004.

Sugirtharajah R. S., Exploring Postcolonial Biblical Criticism: History, Method, Practice, Oxford 2012.

Tarran M., The Orthodox Mission in the North Caucasus - End of $18^{\text {th }}$ - Beginning of the $19^{\text {th }}$ Century, "Central Asian Survey" 10 (1991) no. 1-2, p. 103-117.

Urry J., John Melville and the Mennonites: A British Evangelist in South Russia, 1837 ca. 1875, "Mennonite Quarterly Review" 54 (1980), p. 305-322.

Waterfield R., Christians in Persia. Assyrians, Armenians, Roman Catholics and Protestants, London 1973.

Williams P., 'Not Transplanting': Henry Venn's Strategic Vision, in: The Church Missionary Society and World Christianity 1799-1999, eds. K. Ward, B. Stanley, London 2000, p. $147-172$.

Zacek J. C., The Russian Bible Society and the Russian Orthodox Church, "Church History" 35 (1966) no. 4, p. 411-437.

Zhuk S. I., Russia's Lost Reformation: Peasants, Millennialism, and Radical Sects in Southern Russia and Ukraine, 1830-1917, Washington 2004.

История Грузинской иерархии, с присовокуплением обращения в христианство Осетии и других горских народов, по 1-е января 1825 года, Москва 1826.

О Библейских Обществах и учреждении таковаго же в Санктпетербурге, Санкт-Петербург.

Савинский С. Н., История евангельских христиан-баптистов Украинь, России, Белоруссии, Санкт-Петербург 1999.

Садо С. М., Российская православная миссия в Урмии (1898-1918), “Христианское чтение” 1996 № 13, p. 73-112. 